\title{
Assessing Non-Point Source Pollution Models: a Review
}

\author{
Joy Tuoyo Adu, Muthukrishna Vellaisamy Kumarasamy*
}

Civil Engineering Programme, School of Engineering, University of KwaZulu-Natal, Durban, South Africa

Received: 5 June 2017

Accepted: 19 August 2017

\begin{abstract}
Although access to clean and potable water is a requirement for healthy living, the constant release of non-point source pollutants into water bodies has resulted in water quality degradation. In a bid to curb this situation, water quality models are used as a tool. This study reviews 10 non-point source models, namely: AGNPS, ANSWERS, CREAMS, SWRRB, HSPF, SWAT, EPD RIV1, DMA, CMBA, and MA, giving consideration to their nature, components, area of use, strengths, and limitations. Our review indicated that hydrological processes and mechanisms involved in the movement of non-point source pollutants have not been completely developed in these models. However, HSPF and EPD RIV1 models (which have in-stream process components) are limited due to limitations in their operations and computational difficulties. Further research would seek to develop a non-point source pollutant model that would not only adequately and effectively simulate non-point source pollutants in water bodies, but would also be easy to assess, user-friendly, and time-efficient.
\end{abstract}

Keywords: non-point source pollution, water quality, hydrological processes, water quality models, water quality degradation

\section{Introduction}

Water is necessary for meeting agricultural, industrial, and domestic needs. Unfortunately, population growth, unplanned urbanization, and industrialization have resulted in increased pollutant loadings into water bodies that cause distortions to its ecosystem and are also detrimental to human health [1]. Pollutants that enter streams from identifiable sources are easily recognized and given due attention. However, a greater challenge comes from pollutants generated from unidentifiable sources considered non-point sources (NPS).

*e-mail: kumarasamy@ukzn.ac.za
NPS pollutants originate through runoff from agricultural areas, informal settlements, and contaminated lands [2-4]. Due to their ubiquitous nature, they degrade the natural environment and constitute a health risk. NPS pollution is considered a leading threat to water quality and an unmanageable water pollution problem in many regions of the world [5-7].

\section{Non-Point Source Pollution}

Non-point source pollutants discharge into water bodies through several outlets and in uncertain quantities [8]. They are not easily traced to a source but are linked to weather and geographic conditions within a catchment and maintain an active presence within the ecosystem due to the storage characteristics within the 
receiving basin [8-10]. NPS are characterised by varying spatial and temporal pollutant loading, and complex processes and mechanisms with arbitrary and irregular occurrence [11]. It is presumed more complicated for point source pollution due to its complexities in monitoring and control - especially during monsoon periods [12-14].

Runoff from various watersheds in monsoon season picks up pollutants that contaminate and alter the biological, physical and in some cases chemical properties of a water body [ 5, 15-17]. Discharge of non-point source pollutants into a water channel has a significant effect on water quality [18]. Water quality deterioration resulting from nonpoint source (NPS) pollution is being studied globally [19, 20]. Recent studies have established the impact of NPS pollutants in water environments. Lee et al. [21] observed that NPS contaminants constituted $69.3 \%$ of the total pollution loads discharged from 4 major watersheds in Korea in 2010. Hu and Huang [22] monitored NPS from an agricultural watershed in southern China. The results put the percentage of NPS pollution against total pollutant loads at more than $80 \%$ between 2008 and 2010 .

An investigation into eutrophication of Dianchi Lake by Chen [23] revealed that total nitrogen (TN) and phosphorus (TP) generated by NPS pollution in the lake made up $4.5 \%$ and $26.7 \%$ of the total pollution load. In another study, Chen et al. [24] observed a similar trend of major contributions of TN and TP from NPS to the total pollution loading in the Jinjiang River, China. In the USA NPS pollutants made up $73 \%$ of the total chemical oxygen demand (TCOD), $89 \%$ of TN, and $83 \%$ of bacteria in rivers [25], while in South Africa according to Pegram and Bath [26], 85\% of total contaminants in the Mgeni River basin are from NPS.

Further studies have been carried out on the effect of NPS pollutants on water quality in water bodies [14; 27-31]. Chasing storm events, identifying safe and representative sampling locations and catchments, and the delineation of runoff quality parameters proved a major challenge to assessing NPS pollutants by most researchers. This is largely due to the fact that the mechanisms and hydrological processes required in pollutant migration are not adequately catered for in currently available models [13]. However, these challenges were overcome by the use of remote sensing and GIS techniques in estimating the NPS inflow percentages in the water bodies.

The use of remote sensing and GIS is found to be effective in delineating basin areas that contribute NPS pollutants in water columns. Despite the use of this technique, however, most researchers recorded some margin of error. Considering that approximately $30-50 \%$ of the world's land surface is affected by NPS pollutants [32], accurate simulation and estimation of NPS is necessary to critically address NPS pollution.

\section{NPSP Modelling}

Water quality models (WQM) were developed to determine the rate at which receiving bodies disperse pollutants and ascertain the occurrence of recovery through temporal responses. They were also developed to establish required flow augmentation for improved water quality [33-35]. However, the ever increasing pollution loading in water systems has led to continuous improvement and development of WQM [35].

These upgrades are necessary when considering NPS pollution due to the challenge in identifying its source and quantifying its loading [36]. Furthermore, according to Li et al. [37] and Liu et al. [38], continuous research on NPS pollution modeling is required as there is no universal model that could be used across regions with varying climatic, geographic, and anthropogenic backgrounds.

In studying NPS pollution, modeling has been widely used in attempts to simplify the complex natural processes of generation and transformation of NPS pollutants [39]. Watershed models that simulate hydraulic responses, and receiving water models that simulate water quality and hydrodynamic transport are required to estimate NPS pollutants [40]. The most frequently used watershed models are continuous simulation and storm event models. Continuous simulation models analyze long-term effects of hydrological changes while storm event models examine severe single-storm events.

Only a few models have both long-term continuous and storm event simulation capabilities. Most of them are based on simple empirical relations with robust algorithms, while others use physical-based equations whose numerical solutions are rigorous [41-42]. The simple models are sometimes unable to give the desired result, while the detailed models are inefficient and prohibitive in large watersheds. Therefore, finding an appropriate model for an application and for a certain watershed is quite a challenging task [41].

The use of any model is assessed through the determination of its capability to handle accurately its set out criteria [43]. Over time, extensive work has dealt with the contributing factors of NPS discharges from a watershed into the water body. However, the ultimate effect of the pollutant on the water body and its behavior within the water body is hardly considered.

\section{Review of NPSP Models}

The complex processes that govern NPS pollutants make it difficult to assess and quantify its spatial and temporal extent. Physical and chemical cycles that control the amount of pollutant loading in water bodies are represented using physically based computer modeling.

Numerous models in the public domain have been used successfully in assessing and simulating NPS in watersheds. This review, however, would focus on 
Table 1. Summary of NPS water quality models under review.

\begin{tabular}{|c|c|c|c|c|}
\hline Model & Type & Major components & Strength & Limitations \\
\hline AGNPS & $\begin{array}{l}\text { Event-driven } \\
\text { distributed } \\
\text { model }\end{array}$ & $\begin{array}{l}\text { Hydrology, chemical, } \\
\text { and erosion/sediment } \\
\text { transport }\end{array}$ & $\begin{array}{l}\text { Simulates spatial distribution } \\
\text { of catchment properties; } \\
\text { gives immediate response } \\
\text { compared with experiments; useful } \\
\text { in understanding erosion processes }\end{array}$ & $\begin{array}{l}\text { Requires exclusive and extensive data } \\
\text { and much work and programming } \\
\text { competence; it is unable to assess } \\
\text { nutrient transformation and in-stream } \\
\text { processes }\end{array}$ \\
\hline ANSWERS & $\begin{array}{l}\text { Distributed } \\
\text { parameter, } \\
\text { event-oriented } \\
\text { model }\end{array}$ & $\begin{array}{l}\text { Hydrology, eva- } \\
\text { potranspiration, } \\
\text { infiltration, and } \\
\text { overland sediment } \\
\text { transport }\end{array}$ & $\begin{array}{l}\text { Program codes are easy to modify } \\
\text { and predicted results are } \\
\text { comparable with observed data }\end{array}$ & $\begin{array}{l}\text { Unable to simulate in-stream processes } \\
\text { and simulate sub-processes like } \\
\text { snowmelt or pesticides; requires } \\
\text { elaborate and detailed input data } \\
\text { preparations and is computationally } \\
\text { intensive; output is sensitive to slight } \\
\text { changes in input variables and this } \\
\text { makes its validation challenging }\end{array}$ \\
\hline SWAT & $\begin{array}{l}\text { Continuous, } \\
\text { semi-distribut- } \\
\text { ed, basin-scale } \\
\text { model }\end{array}$ & $\begin{array}{l}\text { Hydrology, climate, } \\
\text { nutrients, sediment } \\
\text { transport }\end{array}$ & $\begin{array}{c}\text { Considers long-term impacts of } \\
\text { rural and agricultural management } \\
\text { practices, and conflux and sediment } \\
\text { confluence; can be used for } \\
\text { specialized processes such as bac- } \\
\text { teria transport }\end{array}$ & $\begin{array}{l}\text { Requires large numbers of input files to } \\
\text { run the model; unable to simulate daily } \\
\text { changes of dissolved oxygen in water } \\
\text { bodies and cannot accurately evaluate } \\
\text { extreme daily flow occurrences, complex } \\
\text { dynamic evolution of soil nitrogen and } \\
\text { carbon, and simulation of runoff yield; } \\
\text { database must be modified when used } \\
\text { in different study areas }\end{array}$ \\
\hline CREAMS & $\begin{array}{l}\text { Field-scale } \\
\text { lumped ap- } \\
\text { proach model }\end{array}$ & $\begin{array}{l}\text { Hydrology, chemical } \\
\text { and erosion/sediment } \\
\text { transport }\end{array}$ & $\begin{array}{l}\text { Forecasts single rainfall events, } \\
\text { calculates runoff volume and storm } \\
\text { loads; can be represented with } \\
\text { simple mathematical terms }\end{array}$ & $\begin{array}{l}\text { Limited simulation capability, } \\
\text { incapable of simulating in-stream } \\
\text { processes High level of competence } \\
\text { is required by user It is easy to misapply } \\
\text { and interpret model outputs }\end{array}$ \\
\hline SWRRB & $\begin{array}{c}\text { Long-term } \\
\text { water and } \\
\text { sediment yield } \\
\text { model } \\
\end{array}$ & $\begin{array}{l}\text { Hydrology, climate } \\
\text { and sediment } \\
\text { transport }\end{array}$ & $\begin{array}{l}\text { Capable of modelling large and } \\
\text { complex watersheds }\end{array}$ & $\begin{array}{l}\text { Incapable of simulating in-stream } \\
\text { processes; input and output files } \\
\text { are massive }\end{array}$ \\
\hline HSPF & $\begin{array}{l}\text { Long-term } \\
\text { continuous } \\
\text { simulation } \\
\text { model }\end{array}$ & $\begin{array}{l}\text { Hydrology, climate } \\
\text { and sediment } \\
\text { transport }\end{array}$ & $\begin{array}{l}\text { Effectively evaluates the flow rate } \\
\text { of runoff, sediment transport, } \\
\text { and nutrient and pesticide } \\
\text { concentrations; predicts results } \\
\text { satisfactorily and is capable of } \\
\text { simulating in-stream processes }\end{array}$ & $\begin{array}{l}\text { Relies on many empirical relationships } \\
\text { to represent physical processes and } \\
\text { requires extensive calibrations and } \\
\text { a high level of expertise; high data sets } \\
\text { are required and it does not consider } \\
\text { the spatial distribution of watersheds; } \\
\text { complex }\end{array}$ \\
\hline EPD-RIV 1 & $\begin{array}{l}\text { One-dimen- } \\
\text { sional } \\
\text { hydrodynamic } \\
\text { model }\end{array}$ & $\begin{array}{l}\text { Hydrodynamic and } \\
\text { water quality }\end{array}$ & $\begin{array}{c}\text { Simulates the impact of time- } \\
\text { varying non-point source pollutants } \\
\text { on water quality and in-stream } \\
\text { processes }\end{array}$ & $\begin{array}{l}\text { Data requirement is high and high level } \\
\text { of expertise required }\end{array}$ \\
\hline DMA & $\begin{array}{l}\text { Mathematical } \\
\text { model }\end{array}$ & Hydrology & $\begin{array}{l}\text { Estimates NPS outflows in } \\
\text { watersheds }\end{array}$ & $\begin{array}{c}\text { Cannot delineate hydrological uniform } \\
\text { areas when subdividing the watershed; } \\
\text { does not consider NPS input as overland } \\
\text { flow }\end{array}$ \\
\hline CMBA & $\begin{array}{l}\text { Mathematical } \\
\text { model }\end{array}$ & $\begin{array}{l}\text { Chemical mass } \\
\text { balance }\end{array}$ & $\begin{array}{c}\text { Estimates non-point loadings } \\
\text { through upstream and downstream } \\
\text { measurements in receiving water } \\
\text { bodies }\end{array}$ & $\begin{array}{l}\text { Is not reliable in accounting for all } \\
\text { pollutants when time of travel between } \\
\text { downstream and upstream is lengthy }\end{array}$ \\
\hline MA & $\begin{array}{l}\text { Mathematical } \\
\text { model }\end{array}$ & $\begin{array}{l}\text { Conservation of } \\
\text { mass and reaction } \\
\text { kinetics }\end{array}$ & $\begin{array}{c}\text { Estimates inflow of NPS } \\
\text { pollutants into a river reach during } \\
\text { both rainy and non-rainy seasons; } \\
\text { the approach assumes NPS input } \\
\text { as overland flow }\end{array}$ & $\begin{array}{l}\text { Is not reliable in accounting for all } \\
\text { pollutants when time of travel between } \\
\text { downstream and upstream is lengthy }\end{array}$ \\
\hline
\end{tabular}


agricultural non-point source (AGNPS), areal nonpoint source watershed environment response simulation (ANSWERS), and soil and water assessment tool (SWAT) models. Others include chemicals, runoff, and erosion from the agricultural management systems (CREAMS), simulator for water resources in rural basins (SWRRB), and hydrological simulation program FORTRAN (HSPF) models. The one-dimensional riverine hydrodynamic and water quality model (EPDRIV1) will also be considered. The choice of the models under review was according to their wider use and availability.

\section{Agricultural Nonpoint Source Pollution Model}

AGNPS is an event-driven and distributed parameter model developed by the United States Department of Agriculture (USDA) Agricultural Research Service. It simulates runoff and estimates sediment and nutrient loads from agricultural watersheds for single-storm events [44]. The water quality components of AGNPS are obtained by correlating nutrients and pesticides in runoff. The model calculates and estimates runoff and subsequent soil erosion using universal soil loss equation (USLE). Furthermore, it uses the unit hydrograph for the uniform rainfall and soil conservation service (SCS) runoff curve approach. AGNPS consists of three principal components [44]: hydrology for calculating peak flow rate and runoff volume, chemical transport for estimating chemicals such as nitrogen $(\mathrm{N})$ and phosphorus $(\mathrm{P})$, and erosion and sediment transport.

AGNPS is considered a very practical tool used in various watersheds to study the impacts of different land cover scenarios [45]. Land use parameters for specifying field processes and weather data required in AGNPS include cropland, pasture, rangeland, forest, urban areas, precipitation, temperature, and sky cover. AGNPS is suitable for interfacing with GIS to accelerate data input and interpret model results [46]. AGNPS is a useful tool in understanding erosion processes and locating areas that have a high potential for loss of nutrients within a watershed [13]. It simulates the spatial distribution of catchment properties using a square grid cells system and evaluates the surface runoff for individual grid cells. The estimated runoff is routed through individual grids within the catchment toward the drain outlet.

Different scenarios for minimizing nutrient and sediment discharge may be simulated, giving the user an advantage of immediate response compared with real-life experiments [39]. AGNPS is a useful tool for management decisions regarding watersheds [13]. The model is predominantly used in the United States. However, its effective use in other regions has been tested [13, 47-48]. AGNPS is not without its limitations.

Catchment scale models like AGNPS require exclusive and extensive data, as the simulation is based on the unit grid, which requires a large number of input parameters. Technical documentation only exists for the input editor of AGNPS, where all the parameters are entered and edited. Moreover, adaptation of the model requires much work and programming competence [49]. The model is incapable of assessing nutrient transformation and in-stream processes and is only capable of simulating single events [40].

Due to the limitations observed in AGNPS as an event-based model, an annualized version AnnaAGNPS was developed to improve the simulation capability of AGNPS to evaluate the long-term effects of NPS pollutants in large watersheds [50].

\section{Areal Nonpoint Source Watershed Environment Response Simulation Model}

ANSWERS is a distributed parameter and event-oriented model developed by the agricultural engineering department of Purdue University [51]. The primary use of ANSWERS is in planning and evaluating strategies for monitoring non-point source pollution from agricultural lands. The model predicts runoff, infiltration, evapotranspiration and sediment transport in agricultural watersheds.

In this model, the hydrological response to a storm event is the mechanism for the movement of pollutants in the watershed. The model requires the subdivision of watersheds into square grids and simulates the processes within the watersheds following rainfall events. The processes that include runoff, sedimentation, and erosion are evaluated and routed for individual cells [13]. Further, ANSWERS produces a number of output data that includes sediment yield hydrographs, runoff hydrographs, chemical movement masses, sediment loss, and deposition masses for the individual cells. Program codes are easy to modify using ANSWERS due to its modular program structure. However, its modeling capability of water quality constituents is limited to nitrogen and phosphorous, but the degradation of nitrogen and phosphorus in-stream is not considered.

ANSWERS is unable to simulate many subprocesses including snowmelt processes or pesticides. The model - like all distributed parameter models - requires elaborate and detailed input data preparations and is computationally intensive. Its output is sensitive to slight changes in input variables and this makes its validation challenging [52]. The erosion module of ANSWERS is empirical to a great extent.

\section{Soil and Water Assessment Tool Model}

SWAT is a continuous, semi-distributed and basinscale model developed for the agricultural research service (ARS) of the USDA [53]. It is physically based and operates on a daily time step. SWAT combines and expands the features of models like CREAMS [54] and SWRRB [55]. The model enables users to consider long-term impacts of rural and agricultural management practices. It considers the process of conflux and 
sediment confluence and develops soil and water conservation modules when combined with GIS.

The major processes of SWAT include climate, soil type, sediment, nutrients, pesticides, vegetation growth, agriculture management, and surface and underground runoff. Additionally, its primary consideration is water, sediments, and chemical yields from agricultural lands in complex watersheds under differing soil types and management conditions. SWAT is used for more, including estimating streamflow and nutrient loading in various watersheds [56].

The model works by dividing the watershed into subunits known as hydrologic response units (HRUs) of similar soil types, land uses, and slopes [57]. SWAT has a high calculative efficiency and is effective for simulating big basins without much time and high investment involved. It is sensitive to changes in climate, plant cover, and management processes [58]. Though easy to use, an ArcGIS interface is required to facilitate simulation setup and modification due to large numbers of input files required to run the model. SWAT is only able to route one pesticide each time through the stream network. It is unable to simulate daily changes of dissolved oxygen in water bodies. [40, 59].

SWAT cannot accurately evaluate processes such as extreme daily flow occurrences, the complex dynamic evolution of soil nitrogen and carbon, and simulation of runoff yield $[42,56]$. It is incapable of simulating single flood events, while its database must be modified when used in different study areas. Among several studies, MiSeon Lee et al. [60] used SWAT and QuickBird highresolution satellite imagery to evaluate the reduction effect of non-point source pollution by applying best management processes (BMPs) in a select watershed. Poudel et al. [61] monitored the quality of surface water in Louisiana using SWAT. Xu et al. [28], using SWAT, estimated nonpoint source pollution loads in the Zhangweinan river basin.

In addition, SWAT was adopted along with the small-scale watershed extended method (SWEM) for the simulation of NPS in Three Gorges Reservoir Region [17;62-64]. Findings from these studies highlighted the strengths and flaws of the model. SWAT is the most widely used model when considering non- point source pollution and best management processes [37].

\section{Chemicals, Runoff, and Erosion from Agricultural Management Systems Model}

CREAMS is a field-scale lumped approach model developed by the USDA to assess agricultural management practices and pollution control [54]. The model calculates runoff volume, peak flow, infiltration, soil water content, percolation, and evapotranspiration on a daily basis. It determines storm load, average sediment concentrations, and dissolved chemicals in the runoff. The analysis is executed through interconnecting sub-models of hydrology, erosion, and chemistry [54]. The application of CREAMS varies from simple to complex systems - especially in extreme cases of climate and management approaches [65]. In developing the model, some assumptions were made to simplify the complex systems and processes so that they are represented by simple mathematical terms. CREAMS employs SCS and USLE for continuous series and erosion simulation processes [54]. Furthermore, it has the ability to forecast single rainfall events that provide an average value for long-term rainfall. The simulated area in CREAMS is limited to a small field with the assumptions that the field has homogeneous soil, land use, and precipitation occurrences. The model has limited simulation capability for snow buildup, snowmelt, and subsequent runoff, and is limited in data management.

CREAMS cannot provide process information or be used for large-scale river basins. It is also incapable of simulating in-stream processes [66]. Users face certain restrictions if the model is run as 3 separate components. Because files generated by a component must first be recorded in order to pass the correct file to the next component, the user must be attentive to the numerous files that would be generated for specific situations and be aware of the assumptions and intrinsic limitations of the model to prevent misapplication or interpretation of the model outputs [54].

\section{Simulator for Water Resources in Rural Basins Model}

SWRRB was developed by modifying subroutines of CREAMS for the simulation of basin-scale processes in rural basins [55]. It is a long-term water and sediment yield simulator capable of predicting the effect of management decisions and assessing water quality in ungauged rural basins. The model consists of three components: hydrology, climate, and sedimentation. Furthermore, it considers both soluble pollutants and sediment-attached pollutants from surface runoff, percolation, evapotranspiration, return flow, transmission losses, reservoir storage, sedimentation, and crop growth [67].

Total nitrogen and phosphorus are evaluated using relationships between runoff volume, sediment yield, and chemical concentration. Surface runoff volume is measured using the SCS curve number, while return flow is evaluated in relation to soil water content and travel time of return flow.

SWRRB effectively models large and complex watersheds that are subdivided based on soil, land use, or management. It is, however, incapable of simulating in-stream processes [67]. And its input and output files are massive.

\section{Hydrologic Simulation Program FORTRAN} (HSPF)

Developed by the United States Environmental Protection Agency (USEPA), HSPF is a comprehensive 
package that simulates watershed hydrology and water quality over land, in-stream, and in impoundments [68]. It is a broad watershed hydrology and water-quality model that allows for the integrated simulation of land and soil contaminant runoff processes. It simulates instream hydraulics, nutrients, and sediment chemical exchanges for a wide range of organic pollutants $[40,69]$. HSPF effectively evaluates the flow rate of runoff, sediment transport, and nutrient and pesticide concentrations. It generates time series results for water quality and quantity within a watershed [70]. Furthermore, the model is used in assessing land-use change and flow diversions for point source and nonpoint source pollutant management processes [71].

Runoff capabilities in HSPF include simple relationships as empirical buildup, wash-off, and concentrations, and detailed soil process options. The in-stream nutrient processes include phosphorus and nitrogen reactions, and $\mathrm{BOD}, \mathrm{DO}, \mathrm{pH}$, benthic algae, phyto, and zooplankton [70]. HSPF divides watersheds into homogeneous segments using the HRU concept. The model ignores the spatial variations within subwatersheds, assumes overland flow to be uni-directional, and considers the receiving water system as completely mixed. Any time-step may be simulated from as little as a minute to upwards of several years. However, HSPF relies on many empirical relationships to represent physical processes requiring extensive calibrations and a high level of expertise.

HSPF does not consider the spatial distribution of watersheds, resulting in increased model complexity. The model also does not consider simulation time as it approaches a distributed model when smaller subwatersheds are used. HSPF is limited to well-mixed rivers and reservoirs and one-dimensional flow [40].

\section{One-Dimensional Riverine Hydrodynamic and Water Quality Model}

EPD-RIV1 is a one-dimensional model developed by Ohio State University for the USEPA as a modification of the CE-QUAL-RIV1 model [34]. The model employs the 2-point 4th-order Holly-Preissman scheme to solve mathematical formulations.

EPD-RIV1 consists of two components: hydrodynamic (RIV1H) and water quality (RIV1Q). RIV1H simulates the dynamics in water bodies to analyze prevailing dynamic conditions and waste load allocations within the water column. RIV1Q has the capacity to simulate water temperature, phosphorus species, nitrogen species, carbonaceous biological oxygen demand (CBOD), dissolved oxygen (DO), algae, manganese, iron, and coliform bacteria. Furthermore, it has the capacity to simulate the impact of time-varying non-point source pollutants on water quality and instream processes. However, the two components are not run simultaneously.

RIV1H is applied first, and the output is written in a file that is transferred and used for simulation in RIV1Q.
EPD-RIV1 evaluates longitudinal variants in hydraulic and water quality characteristics where lateral and vertical differences are small. Additionally, it predicts water surface elevations, flows, depths, velocities, and other hydraulic characteristics. The model uses differential equations to represent a change in values of variables, with one-day time step [34, 72].

In the application of EPD-RIV1, the assumption that the waterbody is one-dimensional is made. This assumption considers that velocities are suitably represented as average values over the cross-section. Furthermore, it assumes that mixing in the lateral and vertical cross-sections are adequate, thereby allowing for cross-sectional homogeneity. This assumption may not be absolutely true, since contaminants discharged into a waterway may not mix completely for some distance downstream. It is, therefore, inappropriate in areas where complete mixing has not taken place [72]. The hydrodynamic model solves the St. Venants equations as the governing flow equations and includes both point and non-point source inflows and outflows. The software has computer system shell, deliberator, preprocessor, post-processor, and pre-run. The required input data consists of initial conditions, geometric data, control and hydraulic parameters, and calibration data. However, data requirement is high $[34,72]$.

The governing equation is:

$$
\frac{\partial \alpha}{\partial t}+\bar{u} \frac{\partial \alpha}{\partial x}=D \frac{\partial^{2} \alpha}{\partial x^{2}}+\frac{q}{A}(\gamma-\alpha)-K_{s} \alpha+\text { Sinks }
$$

...where $\alpha=$ mass concentration $\left(\mathrm{ML}^{-3}\right), \mathrm{t}=$ time $(\mathrm{T})$, $\bar{u}=$ velocity $\left(\mathrm{LT}^{-1}\right), \mathrm{x}=$ longitudinal distance $(\mathrm{L})$, $\mathrm{D}=$ dispersion coefficient $\left(\mathrm{L}^{2} \mathrm{~T}^{-1}\right), \quad \mathrm{A}=$ cross sectional area $\left(\mathrm{L}^{2}\right), \mathrm{q}=$ lateral inflow rate $\left(\mathrm{L}^{3} \mathrm{~T}^{-1} \mathrm{~L}^{-1}\right)$, $\gamma=$ concentration of the runoff input to the channel by distributed flow $\mathrm{K}_{\mathrm{s}}=$ biochemical uptake or decay rates $(+)$ and growth rates $(-)\left(\mathrm{T}^{-1}\right)$, and sinks $=$ biochemical sources(+) and sinks(-).

\section{Other Attempts at Modelling NPS}

Recently, however, attempts at modelling NPS have seen the emergence of mathematical models using several approaches.

\section{Distributed Modelling Approach}

DMA is used in the estimation of NPS outflow from agricultural watersheds to a water column. It involves the collection of data from each field within a watershed by dividing it into small regular units. However, a major challenge is delineating hydrological uniform areas when subdividing the watershed [73]. The commonly used equation for agricultural watersheds is expressed as:

$$
C_{\text {out }}=\frac{1}{100 R_{\text {off }}}(1-k)\left(C_{\text {in }}+C_{n p}\right)
$$


...where $\mathrm{C}_{\text {out }}$ is the soluble concentration of the water quality constituent leaving the reach $\left(\mathrm{ML}^{-3}\right)$, $\mathrm{C}_{\text {in }}$ is the soluble concentration of the water quality constituent entering the reach $\left(\mathrm{ML}^{-3}\right), \mathrm{C}_{\mathrm{np}}$ is the soluble concentration of the NPS constituent generated within the river reach $\left(\mathrm{ML}^{-3}\right), \mathrm{R}_{\text {off }}$ is total runoff $(\mathrm{mm})$, and $\mathrm{k}$ is the decay coefficient $\left(\mathrm{T}^{-1}\right)$.

In the distributed modelling approach, the dissolvable concentration of NPS pollutants is combined with the reduction occurrences of the soluble concentration of water quality constituents at the inlet of the water column. This situation, however (according to Jha et al. [9] and Leon et al. [73]), is not consistent with actual field conditions. Rather, NPS pollutants enter the water column through the overland flow adjacent to it [9].

\section{Chemical Mass Balance Approach}

CMBA is as represented in Eq. 3 [9, 74]. The equation estimates the magnitude of NPS as the difference between the sum of watershed discharge and point source discharges [75]. It has been previously used in indirect estimations of point and non-point loadings through upstream and downstream measurements in receiving water bodies.

$$
Q_{d} C_{d}=Q_{u} C_{u}+\sum_{i=1}^{n} L_{i}
$$

...where $Q_{d}$ and $Q_{u}$ are downstream and upstream discharge $\left(\mathrm{L}^{3} \mathrm{~T}^{-1}\right), \mathrm{C}_{\mathrm{d}}$ and $\mathrm{C}_{\mathrm{u}}$ are downstream and upstream concentrations $\left(\mathrm{ML}^{-3}\right)$, and $\sum_{i=1}^{n} L_{i}$ is the net outcome of individual loadings plus $\stackrel{i=1}{a}$ ny losses or generation within the water body. If significant changes in contaminants occur upstream, the chemical mass balance equation might not be considered reliable in accounting for all pollutants - especially those that undergo significant changes except in conditions where the time of travel between downstream and upstream is small [74].

\section{Modified Approach}

MA is based on the conservation of mass and reaction kinetics. The model estimates the inflow of NPS pollutants into a river reach during rainy and non-rainy seasons [9]. The approach assumes NPSs as uniformly distributed adjacent to the river reach [83]. The limitations observed in the distributed and chemical mass balance approach were tackled using the modified approach indicated as Eq. 4:

$$
Q_{d} C_{d}=Q_{u} C_{u} e^{-k t}+Q_{n p} C_{n p}
$$

...where $\mathrm{Q}_{\mathrm{np}}$ is NPS discharge $\left(\mathrm{L}^{3} \mathrm{~T}^{-1}\right)$, while $\mathrm{k}$ is the rate of attenuation $\left(\mathrm{T}^{-1}\right)$ and $\mathrm{t}$ is travel time $(\mathrm{T})$. This approach was successfully used in estimating nitrate $\left(\mathrm{NO}_{3}\right)$ and ortho-phosphate $\left(\mathrm{o}-\mathrm{PO}_{4}\right)$ loads due to NPS in the River Kali [9]. However, for long reaches the equation would require further modification, as in its present form, the distance between two sampling stations must be as short as possible.

\section{Conclusions}

Ten non-point source pollution models were reviewed: AGNPS, ANSWERS, CREAMS, SWRRB, HSPF, SWAT, EPD RIV1, DMA, CMBA, and MA. The basic operation of each model was carefully highlighted with consideration given to their nature, components, area of use, strengths, and limitations. AGNPS and ANSWERS are single-event, distributed parameter models, while HSPF, CREAMS, and SWAT are long-term continuous simulation models. SWRRB (a modification of CREAMS) simulates basin scale processes. AGNPS, HSPF, CREAMS, and SWAT have three major components comprising chemical, hydrological, and sedimentation components.

AGNPS lacks the capacity to predict sediment, time-varying water, and chemical discharges critical in certain analyses due to its computationally intensive numerical structures. ANSWERS and SWRRB have hydrology and overland sediment as their main components, excluding chemical component and sediment simulation in stream channels. SWRRB, however, has a weather component. ANSWERS and HSPF use storage-based equations for flow routing while AGNPS, CREAMS, SWRRB, and SWAT use SCS runoff curve number to estimate peak flows and runoff volumes. Additionally $\mathrm{HSPF}$ and CREAMS require continuous precipitation data.

It is, however, observed that hydrological processes and mechanisms involved in the movement of pollutants have not been completely developed in these models. The limitations observed in DMA CMBA were addressed by the MA model. However, MA would require further modification in terms of the reach length to be considered, which is vital for non-point source modeling. In view of all models reviewed, both HSPF and EPD RIV1 have the capability of simulating instream processes. However, both HSPF and EPD-RIV1 have limitations that preclude their overall capability in effectively and easily evaluating non-point source pollutants in water bodies.

HSPF relies on a number of empirical relationships to distinguish physical processes. It lumps simulation processes for different land use types at watershed levels and transits to a distributed-type model when the watershed is small, resulting in an increase in simulation time and model complexity. HSPF requires extensive calibrations and a high level of expertise, plus a high data requirement.

EPD-RIV1 is a one-dimensional model comprised of two codes: hydrodynamic (RIV1H) and water quality 
(RIV1Q), which do not run concurrently. RIV1H is applied first and stored before RIV1Q uses its output file to drive the transport of the water quality parameters. The assumption made in EPD-RIV1 on the homogeneity in the cross-section of a water column may not stand true, which makes the model inappropriate in areas where complete mixing has not occurred.

Considering these points, this study concludes that further research is required to develop a non-point source pollution model that would not only adequately and effectively simulate non-point source pollutants in water bodies, but would also be easy to assess, user- friendly, flexible to adopt different water quality parameters, and time-efficient.

\section{Acknowledgements}

The authors express their gratitude for all the support provided by the Water Research Commission in South Africa for this research through project $\mathrm{K} 5 / 2328$.

\section{References}

1. KUMARASAMY M. Deoxygenation and reaeration coupled hybrid mixing cells based pollutant transport model to assess water quality status of a river. International journal of environmental research, 9, 341, 2015.

2. U.S. EPA. National management measures for the control of non-point pollution from agriculture, EPA-841-B-03-004, US Environmental Protection Agency, Office of Water, Washington, DC, 2003

3. LI Q.K., LI H.E. The preliminary frame of non point source pollution study in the Yellow River watershed. Yellow River, 32(12), 131, 2010.

4. FU C., KANG W.Y. Research on spatial characteristics of TN \& TP of agricultural non-point source pollution in the surrounding area of the Poyang lake. Resour Environ Yangtze Basin, 21 (7), 864, 2012.

5. ONGLEY E.D., ZHANG X., YU T. Current status of agricultural and rural non-point source Pollution assessment in China. Environmental Pollution, 158, 1159, 2010.

6. COLLICK A.S., FUKA D.R., KLEINMAN P.J.A., BUDA A.R., WELD J.L., WHITE M.J., VEITH T.L., BRYANT R.B., BOLSTER C.H., EASTON Z.M. Predicting phosphorus dynamics in complex terrains using a variable source area hydrology model. Hydrol. Process., 29 (4), 588, 2015.

7. POUDEL D.D. Surface water quality monitoring of an agricultural watershed for nonpoint source pollution control. Journal of Soil and Water Conservation, 71 (4), 310,2016

8. LOAGUE K., CORWIN D.L. Point and nonpoint source pollution. Encyclopedia of hydrological sciences, 2005 .

9. JHA R., OJHA C.S.P., BHATIA K.K.S. Non-point source pollution estimation using a modified approach. Hydrological processes, 21, 1098, 2007.

10. DONG Y., LIU Y., CHEN J. Will urban expansion lead to an increase in future water pollution loads? - a preliminary investigation of the Haihe River Basin in northeastern
China. Environmental Science and Pollution Research, 21 (11), 7024, 2014.

11. WANG A., TANG L., YANG D. Spatial and temporal variability of nitrogen load from catchment and retention along a river network: a case study in the upper Xin'anjiang catchment of China. Hydrology Research, 47 (4), 869, 2016

12. ZHANG H., HUANG G. H. Assessment of non-point source pollution using a spatial multicriteria analysis approach. Ecological Modelling, 222(2), 313, 2010.

13. SHEN Z., LIAO Q., HONG Q., GONG Y. An overview of research on agricultural non-point source pollution modelling in China. Separation and Purification Technology, 84, 104, 2012.

14. GAO X.P., LI G.N., LI G.R., ZHANG C. Modeling the effects of point and non-point source pollution on a diversion channel from Yellow River to an artificial lake in China. Water Science \& Technology, 71, 1806, 2015.

15. LI J.K. Research on non-point source pollution load quantification for watershed-taking the Weihe river basin as an example. Doctoral dissertation, Xian: Xi'an University of Technology, 2009.

16. WU L., LONG T., LIU X., GUO J. S. Impacts of climate and land-use changes on the migration of non-point source $\mathrm{TN}$ and phosphorus during rainfall-runoff in the Jialing River Watershed, China. J. Hydrol. 475, 26, 2012.

17. SHEN Z., QIU J., HONG Q., CHEN L. Simulation of spatial and temporal distributions of non-point source pollution load in the Three Gorges Reservoir Region. Science of the Total Environment, 493, 138, 2014.

18. HAN L., HUO F., SUN J. Method for calculating non-point source pollution distribution in plain rivers Water Science and Engineering, 4 (1), 83, 2011.

19. MA X., LI Y., ZHANG M., ZHENG F.Z., DU S. Assessment and analysis of non-point source nitrogen and phosphorus loads in the Three Gorges Reservoir Area of Hubei Province, China. Science of the Total Environment, 412, 154, 2011.

20. AMAYA F.L., GONZALES T.A., HERNANDEZ E.C., LUZANO E.V., MERCADO N.P. Estimating Point and Non-Point Sources of Pollution in Biñan River Basin, the Philippines. APCBEE Procedia, 1, 233, 2012.

21. LEE S.C., PARK I.H., KIM B.S., HA S.R. Relationship between non-point source pollution and Korean green factor, Terr. Atmos. Ocean. Sci. 26, 341, 2015.

22. HU H., HUANG G. Monitoring of non-point source pollutions from an agriculture watershed in South China. Journal of Water, 2014.

23. CHEN J.N. Nonpoint Source Pollution Control - Case Studies in Dianchi Lake Catchments, China Environmental Science Press, Beijing, 2009.

24. CHEN H., TENG Y., WANG J. Load estimation and source apportionment of nonpoint source nitrogen and phosphorus based on integrated application of SLURP model, ECM, and RUSLE: a case study in the Jinjiang River, China. Environmental monitoring and assessment, 185 (2), 2009, 2013.

25. ZHAI X., ZHANG Y., WANG X., XIA J. LIANG T. Non-point source pollution modelling using Soil and Water Assessment Tool and its parameter sensitivity analysis in Xin'anjiang catchment, China. Hydrol. Process. 28, 1627, 2014.

26. PEGRAM G.C., BATH A.J. Role of non-point sources in the Development of a water quality Management plan for the Mgeni river catchment. Wat. Sci. Tech, 32 (5-6), 175, 1995. 
27. XIA J., ZHAI X., ZHANG Y. Progress in the Research of Water Environmental Nonpoint Source Pollution Models. Progress in Geography, 31, 941, 2012.

28. XU H.S., XU Z.X., LIU P. Estimation of Nonpoint Source Pollutant Loads and Optimization of the Best Management Practices (BMPs) in the Zhangweinan River Basin. Environmental Science, 3, 10, 2013.

29. QIU Z. Comparative assessment of stormwater and nonpoint source pollution best management practices in suburban watershed management. Water, 5 (1), 280, 2013.

30. WU Y., CHEN J. Investigating the effects of point source and nonpoint source pollution on the water quality of the East River (Dongjiang) in South China. Ecological Indicators, 32, 294, 2013.

31. WU L., LIU X., MA X.Y. Spatio-temporal variation of erosion-type non-point source pollution in a small watershed of hilly and gully region, Chinese Loess Plateau. Environmental Science and Pollution Research, 23 (11), 10957, 2016.

32. PIMENTEL D. World soil erosion and conservation. Cambridge: Cambridge University Press. (Ed.), 1993.

33. BENEDINI M., TSAKIRIS G. Water quality modelling for rivers and streams. Springer Science \& Business Media, 2013.

34. SHARMA D., KANSAL A. Assessment of river quality models: a review. Reviews in Environmental Science and Bio/Technology, 12, 285, 2013.

35. WANG Q., LI S., JIA P., QI C., DING F. A review of surface water quality models. The Scientific World Journal, 2013.

36. MAMUN A.A., SALLEH M.N. Challenges in non-point source pollution - Sampling and testing. In Engineering and Technology (BICET 2014), $5^{\text {th }}$ Brunei International Conference, 1-6. IET, 2014.

37. LI S., ZHUANG Y., ZHANG L., DU Y., LIU H. Worldwide performance and trends in nonpoint source pollution modeling research from 1994 to 2013: A review based on bibliometrics. Journal of Soil and Water Conservation, 69 (4), 121A, 2014

38. LIU X., ZHANG L., HONG S. Global biodiversity research during 1900-2009: A bibliometric analysis. Biodiversity and Conservation, 20 (4), 807, 2011.

39. ZHUANG Y., NGUYEN T., NIU B., SHAO W., HONG S. Research trends in non point source during 19752010. In International Conference on Medical Physics and Biomedical Engineering, ed. D. Yang. Physics Procedia, 138, 2012.

40. SHOEMAKER L., DAI T., KOENIG J., HANTUSH M. TMDL model evaluation and research needs. National Risk Management Research Laboratory, US Environmental Protection Agency, 2005.

41. BORAH D.K, BERA M. Watershed-scale hydrologic and nonpoint-source pollution models: Review of mathematical bases. Transactions of the ASAE, 46 (6), 1553, 2003.

42. BORAH D.K., BERA M. Watershed-scale hydrologic and nonpoint-source pollution models: Review of applications. Transactions of the ASAE, 47 (3), 789, 2004.

43. KLIMENT Z., KADLEC J., LANGHAMMER J. Evaluation of suspended load changes using AnnAGNPS and SWAT semi-empirical erosion models. Catena, 73, 286, 2008.

44. YOUNG R.A., ONSTAD C.A., BOSCH D.D., ANDERSON W.P. AGNPS: A nonpoint-source pollution model for evaluating agricultural watersheds. Journal of soil and water conservation, 44 (2), 168, 1989.
45. DE AUSSEN R., KALITA P.K., KOELLIKER J.K., MANKIN K.R. Application of AGNPS-ARC INFO interface model to an agricultural watershed of Kansas. In: ASAE Paper No. 983139 (St Joseph, eds.). ASAE, MI, USA, 1998.

46. BHUYAN S.J., KOELLIKER J.K., MARZEN L.J., HARRINGTON J. An integrated approach for water quality assessment of a Kansas watershed. Environmental Modelling Software, 18 (5), 473, 2003.

47. MOHAMMED H., YOHANNES F., ZELEKE G. Validation of agricultural non-point source (AGNPS) pollution model in Kori watershed, South Wollo. Ethiopia International Journal of Applied Earth Observation and Geoinformation, 6, 97, 2004.

48. LEON L.F., BOOTY W.G., BOWEN G.S., LAM D.C. Validation of an agricultural non-point source model in a watershed in southern Ontario. Journal of Agricultural Water Management, 65 (1), 59, 2004.

49. FINN M.P., USERY E.L., SCHEIDT D.J., JARONACK G.M., KRUPINSKI T.D. An interface between the agricultural non-point source (ANGPS) pollution model and the ERDAS imagine geographic information system (GIS). Geographic information sciences, 12 (1), 10, 2006.

50. BINGNER R.L., F.D. THEURER. Topographic factors for RUSLE in the continuous simulation watershed model for predicting agricultural, non-point source pollutants (AnnAGNPS), Soil erosion research for the 21st century. Proceedings of the International Symposium, Honolulu, Hawaii, USA, 3, 2001.

51. BEASLEY D.B., HUGGINS L.F. ANSWERS Users Manual. EPA-905/9-82-001, U.S. EPA, Region V. Chicago, IL, 1981.

52. DE ROO A.P.J., HAZELHOFF L. BURROUGH P.A. Soil erosion modelling using 'answers' and geographical information systems. Earth Surf. Process. Landforms, 14, $517,1989$.

53. NEITSCH S.L., ARNOLD J.G., KINIRY J.R., WILLIAMS J.R., Soil and Water Assessment Tool Theoretical Documentation Version 2009. edited, Texas Water Resources Institute, 2011.

54. LEONARD R.A., KNISEL W.G. Model selection for nonpoint source pollution and resource conservation. Proc. of the International Conference on Agriculture and Environment, Venice, Italy. E1-E18, 1984.

55. WILLIAMS J.R., NICKS A., ARNOLD J.G. Simulator for water resources in rural basins. Journal of Hydraulic Engineering, 111 (6), 970, 1985.

56. ABBASPOUR K.C., YANG J., MAXIMOV I., SIBER R., BOGNER K., MIELEITNER J., ZOBRIST J., SRINIVASAN R. Modelling hydrology and water quality in the pre-alpine/alpine Thur watershed using SWAT. Journal of hydrology, 333 (2), 413, 2007.

57. MARINGANTI C., CHAUBEY I., ARABI M., ENGEL B.. Application of a multi-objective optimization method to provide least cost alternatives for NPS pollution control. Environ Manage, 48, 448, 2011.

58. ULLRICH A., VOLK M. Application of the Soil and Water Assessment Tool (SWAT) to predict the impact of alternative management practices on water quality and quantity. Agricultural Water Management, 96, 1207, 2009.

59. BENAMAN J., SHOEMAKER C.A., HAITH D.A. Calibration and validation of soil and water assessment tool on an agricultural watershed in upstate New York. Journal of Hydrologic Engineering, 363, 2005.

60. MISEON L., GEUNAE P., MINJI P., JONGYOON P., JIWAN L., SEONGJOON K. Evaluation of non-point 
source pollution reduction by applying Best Management Practices using a SWAT model and QuickBird high resolution satellite imagery. Journal of Environmental Sciences, 22 (6), 826, 2010.

61. POUDEL D.D., LEE T., SRINIVASAN R., ABBASPOUR K., JEONG C.Y. Assessment of seasonal and spatial variation of surface water quality, identification of factors associated with water quality variability, and the modeling of critical nonpoint source pollution areas in an agricultural watershed. Journal of Soil and Water Conservation, 68 (3), 155, 2013.

62. HONG Q., SUN Z., CHEN L., LIU R., SHEN Z. Small-scale watershed extended method for nonpoint source pollution estimation in part of the Three Gorges Reservoir Region. Int J Environ Sci Technol, 9, 595, 2012.

63. SHEN Z.Y., CHEN L., HONG Q., QIU J.L., XIE H., LIU R.M. Assessment of nitrogen and phosphorus loads and causal factors from different land use and soil types in the Three Gorges Reservoir Area. Sci Total Environ. 454, 383, 2013b.

64. SHEN Z., CHEN L., HONG Q., XIE H., QIU J., LIU R. Vertical variation of nonpoint source pollutants in the Three Gorges Reservoir Region. Plos One, 8 (8), p.e71194, 2013c.

65. CROWDER B.M., YOUNG C.E. Modeling agricultural non-point source pollution for economic evaluation of the conestoga headwaters RCWP project. U.S Department of Agriculture, Economic Research Service, Natural resources Economic Division, washington, D.C. ERS Staff Report No. AGES850614: 70, 1985.

66. KAUPPI L. Testing the Application of CREAMS to Finnish Conditions. In: Svetlosanov, V., Knisel, W.G., editors. European and United States Case Studies in Application of the CREAMS Model. International Institute for Applied Systems Analysis. Laxenberg, Austria, 43, 1982.

67. ARNOLD J., WILLIAMS J., SINGH V. SWRRB-a watershed scale model for soil and water resources management, Computer models of watershed hydrology, $847, \mathbf{1 9 9 5}$

68. BARNWELL T.O., JOHANSON R. HSPF: A comprehensive package for simulation of watershed hydrology and water quality. In: Nonpoint Pollution Control: Tools and Techniques for the Future. Interstate Commission on the Potomac River Basin, 1055 First Street, Rockville, MD 20850, 1981.

69. RIBAROVA I., NINOVB P., COOPER D. Modeling nutrient pollution during a first flood event using HSPF software: Iskar River case study, Bulgaria. Ecol Mod, 211, 241,2008

70. TZORAKI O., NIKOLAIDIS N.P. A generalized framework for modeling the hydrologic and biogeochemical response of a Mediterranean temporary river basin. J. Hydrology, 346, 112, 2007.

71. CHO J., BARONE V.A., MOSTAGHIMI S. Simulation of land use impacts on groundwater levels and streamflow in a Virginia watershed. Agri Wat Manag, 96, 1, 2009.

72. MARTIN J.L., WOOL T., OLSON R. A dynamic onedimensional model of hydrodynamics and water quality EPD-RIV1 Version 1.0. User's manual by Roy Burke III, Georgia Environmental Protection Division, Atlanta, Georgia, 2002.

73. LEON L.F., SOULIS E.D., KOUWEN N., FARQUHAR G.J. Non-point source pollution: a distributed water quality modelling approach. Journal Water Research, 35 (4), 997, 2001.

74. JAIN C.K. Application of chemical mass balance approach to determine nutrient loading. Hydrological sciences journal, 45 (4), 577, 2000.

75. NOVOTNY V., OLEM H. Water quality: prevention, identification and management of diffuse pollution. Van Nostrand-Reinhold: New York, 1994. 